Columbia Law School

Scholarship Archive

\title{
Burning Down the House? The Appellate Body in the Centre of the WTO Crisis
}

\author{
Bernard Hoekman \\ European University Institute, Robert Schuman Centre for Advanced Studies (RSCAS), \\ bernard.hoekman@eui.eu \\ Petros C. Mavroidis \\ Columbia Law School, petros.mavroidis@unine.ch
}

Follow this and additional works at: https://scholarship.law.columbia.edu/faculty_scholarship

Part of the Dispute Resolution and Arbitration Commons, and the International Trade Law Commons

\section{Recommended Citation}

Bernard Hoekman \& Petros C. Mavroidis, Burning Down the House? The Appellate Body in the Centre of the WTO Crisis, Trade in the 21st Century: Back to the Past?, Bernard M. HoEkMan \& ERnesto Zedillo (EDS.), BROOKINGS INSTITUTION PRESS, 2021; EUROPEAN UNIVERSITY INSTITUTE, ROBERT SCHUMAN CENTRE FOR Advanced Studies, Global Governance Programme Working Paper No. RSCAS 2019/56 (2019).

Available at: https://scholarship.law.columbia.edu/faculty_scholarship/2347

This Working Paper is brought to you for free and open access by the Faculty Publications at Scholarship Archive. It has been accepted for inclusion in Faculty Scholarship by an authorized administrator of Scholarship Archive. For more information, please contact scholarshiparchive@law.columbia.edu. 

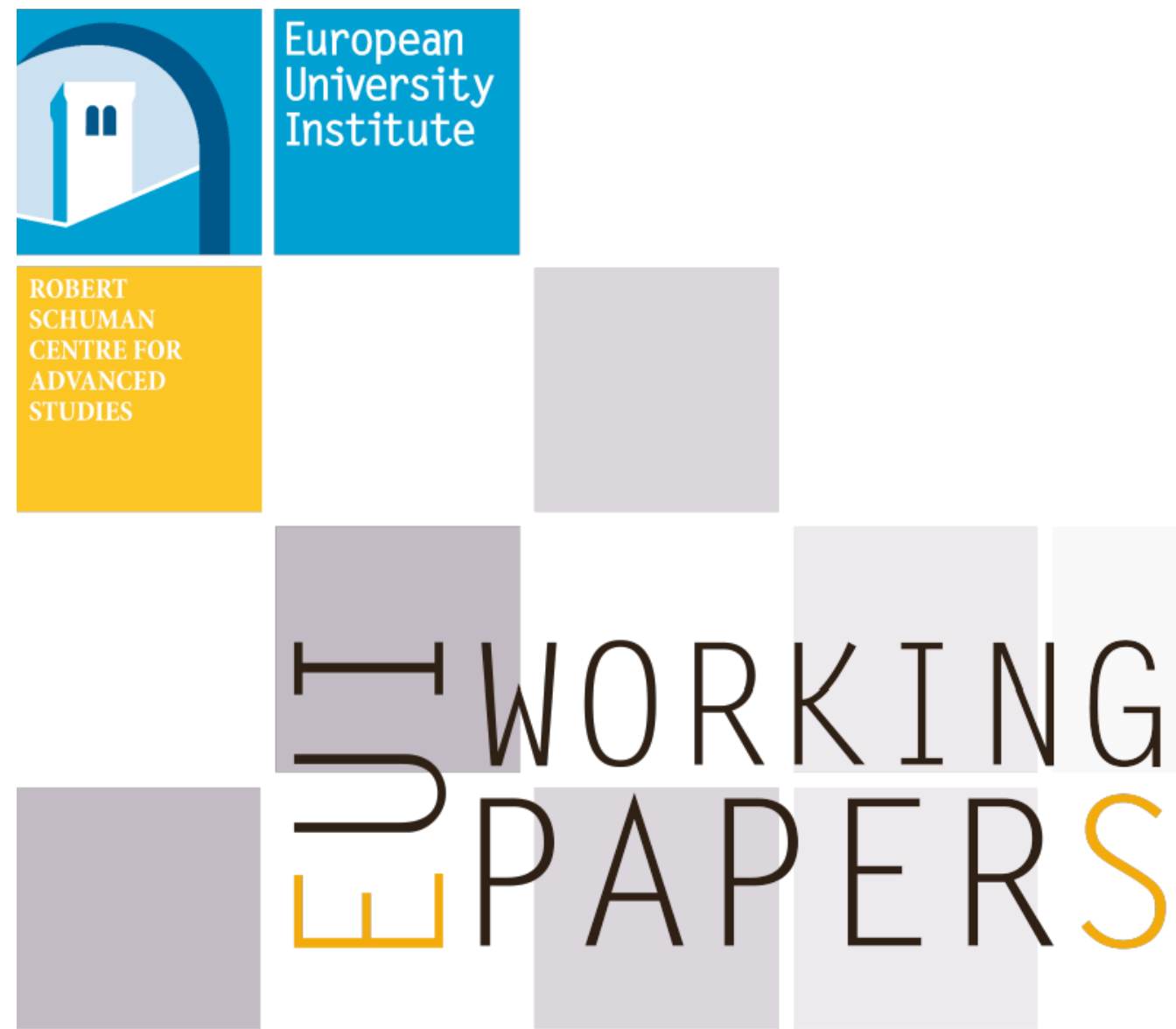

RSCAS 2019/56

Robert Schuman Centre for Advanced Studies Global Governance Programme-353

Burning Down the House?

The Appellate Body in the Centre of the WTO Crisis

Bernard M. Hoekman and Petros C. Mavroidis 
European University Institute

Robert Schuman Centre for Advanced Studies

Global Governance Programme

Burning Down the House?

The Appellate Body in the Centre of the WTO Crisis

Bernard M. Hoekman and Petros C. Mavroidis

EUI Working Paper RSCAS 2019/56 
This text may be downloaded only for personal research purposes. Additional reproduction for other purposes, whether in hard copies or electronically, requires the consent of the author(s), editor(s). If cited or quoted, reference should be made to the full name of the author(s), editor(s), the title, the working paper, or other series, the year and the publisher.

ISSN 1028-3625

(C) Bernard M. Hoekman and Petros C. Mavroidis, 2019

Printed in Italy, July 2019

European University Institute

Badia Fiesolana

I - 50014 San Domenico di Fiesole (FI)

Italy

www.eui.eu/RSCAS/Publications/

www.eui.eu

cadmus.eui.eu 


\section{Robert Schuman Centre for Advanced Studies}

The Robert Schuman Centre for Advanced Studies, created in 1992 and currently directed by Professor Brigid Laffan, aims to develop inter-disciplinary and comparative research on the major issues facing the process of European integration, European societies and Europe's place in $21^{\text {st }}$ century global politics.

The Centre is home to a large post-doctoral programme and hosts major research programmes, projects and data sets, in addition to a range of working groups and ad hoc initiatives. The research agenda is organised around a set of core themes and is continuously evolving, reflecting the changing agenda of European integration, the expanding membership of the European Union, developments in Europe's neighbourhood and the wider world.

For more information: http://eui.eu/rscas

The EUI and the RSCAS are not responsible for the opinion expressed by the author(s).

\section{The Global Governance Programme}

The Global Governance Programme is one of the flagship programmes of the Robert Schuman Centre. It is a community of outstanding professors and scholars that produces high quality research and engages with the world of practice through policy dialogue. Established and early-career scholars work on issues of global governance within and beyond academia, focusing on four broad and interdisciplinary areas: Global Economics, Europe in the World, Cultural Pluralism and Global Citizenship.

The Programme also aims to contribute to the fostering of present and future generations of policy and decision makers through its executive training programme: the Academy of Global Governance, where theory and 'real world' experience meet and where leading academics, top-level officials, heads of international organisations and senior executives discuss on topical issues relating to global governance.

For more information: http://globalgovernanceprogramme.eui.eu

The European University Institute and the Robert Schuman Centre are not responsible for the opinions expressed by the author(s). 


\begin{abstract}
In December 2019 the WTO Appellate Body (AB) will cease to operate unless the United States stops blocking new appointments. The US argues the AB has exceeded its mandate and has indicated it wants to ensure that the $\mathrm{AB}$ performs the role originally assigned to it in 1995. This paper discusses the Uruguay round negotiating history with the view to establish what "going back to 1995" entails. It concludes that this should not be difficult assuming a willingness of the WTO membership to seriously consider the US concerns and acceptance by the US of a commitment by the membership to ensure that the AB operates consistently with its 1995 mandate.
\end{abstract}

\title{
Keywords
}

Dispute settlement, Appellate Body; WTO; Uruguay round

\section{JEL classification}

F13; K40 


\section{Introduction*}

And then there were ... three. Following months of threats, and eventually actions, as of the time of writing (July 2019) the number of the Appellate Body (AB) members has dropped to three, down from the full complement of seven members called for by the WTO Dispute Settlement Understanding (DSU). In December 2019 the number will fall to one if the United States continues to block new appointments to replace sitting members as their terms expire. The progressive reduction in membership of the $\mathrm{AB}-$ from seven to six, to five, to four, to three - has led to a blame game. The US delegation to the WTO has time and again expressed the view that its actions are simply guided by its desire to ensure that the $\mathrm{AB}$ performs the institutional role assigned to it in the agreement negotiated in Uruguay Round and that is reflected in text of the DSU. The US argues that the AB has not abided by its terms of reference, and that the $\mathrm{AB}$ has in various ways acted as if it were a principal instead of an agent, as it is required to do as per Article 3.2 of the DSU. As a result, it argues, drastic action was required to bring it back to order. While the United States is the prime mover in forcing the Appellate Body crisis, others have played along. The rest of the WTO membership has not been willing to address the situation head-on by pushing for majority decisions in this respect, as it can do under Article IX.1 of the Agreement Establishing the WTO. ${ }^{1}$ Instead, several WTO members have submitted proposals to anticipate a situation in which the $\mathrm{AB}$ becomes defunct. The European Union for example, has suggested WTO members consider an AB à la carte: using Article 25 of the DSU as legal scaffolding, two disputing parties would consent to the establishment of a body that would act as an appeals board.

The dispute on the WTO dispute settlement mechanism has led the WTO membership into no man's land. As things stand, no one can predict what will happen after December 11, 2019, when there will be only one $\mathrm{AB}$ member left. What if, for example, a losing party appeals a panel report and there is no $\mathrm{AB}$ to adjudicate it? What would, in this case, the legal status of the appealed panel report be? The various "plan B" proposals that have been proposed by some WTO members are second-best stop-gaps at best. Take the EU proposal, for example, in which parties to a dispute agree to adopt a panel report or to make recourse to arbitration. For this to work, the consent of the defendant is necessary. But the whole purpose of the DSU was to move to negative consensus. ${ }^{2}$

Unfortunately, none of the proposals put forward to date addresses the real issue raised by the US: its call for measures to ensure that the AB operates as intended when the WTO entered into force in 1995. Notwithstanding speculation that some in the US would prefer to go back to the GATT system of dispute settlement in which the establishment of a panel and adoption of reports by panels could be blocked, the US has made clear it is not questioning the premise of binding and automatic dispute settlement.

Clear differences in view exist between WTO members whether the AB has sidestepped or exceeded its mandate. To assess whether and where the $\mathrm{AB}$ has done so it is necessary to have a common understanding of what the original intent was. This paper asks what the framers wished to achieve

This paper is part of a broader project with Robert Wolfe. We are grateful to President Trump for providing the quintessential input for this study. We are further happy to acknowledge the EU nonchalance in addressing some of the issues discussed here. We are also grateful to Rodd Izadnia, Gabrielle Marceau, Ernst-Ulrich Petersmann, Neeraj R.S., Debra Steger for helpful discussions and comments on prior drafts. The project leading to this paper received funding from the European Union's Horizon 2020 research and innovation program under grant agreement No 770680 (RESPECT).

1 Art. IX(1) states that except as otherwise provided, where a decision cannot be arrived at by consensus, the matter at issue shall be decided by voting, with each Member of the WTO having one vote, and decisions of the Ministerial Conference and the General Council taken by a majority of the votes cast, unless otherwise provided in the WTO Agreement itself or the relevant Multilateral Trade Agreements.

2 We understand of course, that the EU proposal is to allow for ad hoc recourse to Article 25. If the European Union wished to formalize its proposal it would have to propose an amendment, which would require consensus before it could be enacted. 
through the establishment of the $\mathrm{AB}$, and the eventual mandate of the $\mathrm{AB}$, through the lens of the relevant negotiating documents. We investigate what the negotiating record tells us about the intended function of the $\mathrm{AB}$. Our premise is that unless we have established this picture, it will be hard to take positions with respect to current views of the membership regarding the $\mathrm{AB}$ and what should understood by the US position that the AB needs to "go back to 1995."

We take at face value the purpose of the $\mathrm{AB}$ that is reflected in the rather un-informative Article 3.7 of the DSU. Art. 3.7 states that the

\begin{abstract}
"... aim of the dispute settlement mechanism is to secure a positive solution to a dispute. A solution mutually acceptable to the parties to a dispute and consistent with the covered agreements is clearly to be preferred. In the absence of a mutually agreed solution, the first objective of the dispute settlement mechanism is usually to secure the withdrawal of the measures concerned if these are found to be inconsistent with the provisions of any of the covered agreements. The provision of compensation should be resorted to only if the immediate withdrawal of the measure is impracticable and as a temporary measure pending the withdrawal of the measure which is inconsistent with a covered agreement. The last resort which this Understanding provides to the Member invoking the dispute settlement procedures is the possibility of suspending the application of concessions or other obligations under the covered agreements on a discriminatory basis vis-à-vis the other Member, subject to authorization by the DSB of such measures."
\end{abstract}

We juxtapose the US critique of the operation of the $\mathrm{AB}$ against this provision, which reflects what was negotiated and agreed by the Uruguay Round negotiators. Our aim is to take seriously the desire expressed by the United States to "go back to 1995" - i.e., that the AB does no more and no less than what was agreed in the Uruguay Round. We do not ask whether the AB has helped achieve compliance with the WTO, or more generally assess its contribution. Nor do we express a view whether the US chose the appropriate means to advance its dispute settlement agenda. ${ }^{3}$ We take as given the situation with respect to the $\mathrm{AB}$ as it has emerged, whether this is the result of US intransigence and/or nonchalance or a preference for second-best solutions by the rest of the WTO membership.

We also do not enter into a comprehensive discussion why and how the $\mathrm{AB}$, too often referred to as the crown-jewel of the trading system in the academic literature, turned from venerable to vulnerable like a modern Cinderella. Any such discussion would necessarily entail considering the selection process for $\mathrm{AB}$ members, the quality of the chosen individuals, the role of the WTO Secretariat, and so forth. It is the AB 1.0 that we are after, the original design as determined in 1995. Our approach is to review the legitimacy of the US complaints against the intended function of the $\mathrm{AB}$ - the original mandate - as revealed not only by the text of Art. 3.7 DSU (see above) but by the negotiating record.

We start in Section 2 with a brief discussion of the AB powers and mandate as reflected in the current DSU provisions, followed by a discussion of the negotiating record. We then provide a taxonomy of the major players and their respective negotiating positions, and demonstrate that the negotiation of the $\mathrm{AB}$ was not a priority issue for any of them. The establishment of an appeals board was proposed just twelve months before the end of substantive negotiations. Against this background, Section 3 discusses the complaints that the United States has formulated towards the AB. In Section concludes.

\title{
2. The Uruguay Round AB Negotiations
}

As we discuss in more detail below, the $\mathrm{AB}$ was designed to provide the last word in a system of compulsory third-party adjudication under the aegis of the WTO. The text of the DSU - the statute administering dispute adjudication at the WTO - comprises 11 provisions (articles) dedicated to the

3 For example, one could ask whether it would have been more appropriate for the United States to seek alliances in the realm of the ongoing DSU Review to "instrumentalize" its criticism of the AB. This raises important considerations associated with WTO working practices, notably consensus, which would affect the salience of any such effort. We leave this aside in this paper. 
work of panels (Articles 6-16). Only one provision deals exclusively with the AB (Article 17). Two others concern both panels and the AB (Articles 18, 19).

The negotiating record explains this imbalance in the text. When the Uruguay round was launched in 1986 no one had thought of a two-instance adjudication process. The AB, or an appeals board to be more precise, only was proposed at the end of 1989, relatively close to the end of the substantive negotiations in the Uruguay round. The negotiating record, to which we refer in what follows, leaves no doubt in this respect. We kick off our discussion with the current statutory provisions concerning the function of the $\mathrm{AB}$, before we travel back in time to discuss how we ended up where we now are.

\subsection{The AB and its Statutory Role in WTO Dispute Settlement}

As mentioned, the DSU has only one provision dedicated to the AB, Article 17. Most of the text in this provision deals with matters of peripheral importance, such as the deadlines for issuing reports, the confidentiality of its proceedings, etc. Only one paragraph (para. 13), deals with the function of the AB:

The Appellate Body may uphold, modify or reverse the legal findings and conclusions of the panel.

Unsurprisingly, the absence of an initial, elaborate legislative design resulted in some glaring omissions. The most obvious omission is the absence of a provision regarding the standard of review for the AB. Article 11 of the DSU addresses this issue only insofar as panels are concerned. It was thus left to case law to fill the gaps (standing case law, for example, makes it clear that Article 11 of the DSU applies to the AB as well), as well as through "secondary" law. Article 17.9 of the DSU mandates the AB to adopt its own Working Procedures, and address matters not covered in the DSU.

Being part and parcel of the WTO dispute adjudication process, the AB has to adjust its workings within the statutory parameters reserved to the functioning of WTO adjudication. In this respect, the key provision is Article 3.7 of the DSU, which establishes a hierarchy of objectives that adjudication at the WTO-level must serve, namely:

- The prime objective of WTO adjudication is to secure a mutually acceptable solution (MAS) between the parties to the dispute

- If reaching a MAS proves an impossibility, it is the withdrawal of the challenged measure that is privileged, assuming of course, that it has been found to be inconsistent with the WTO law;

- The WTO regime has a clearly expressed statutory preference for property- over liability rules: ${ }^{4}$ compensation of the injured party, if this is accorded, is temporary, until withdrawal of the illegal measures has been secured;

- Finally, suspension of concessions is the ultimate ratio, the last resort to which the winning party can have recourse to in order to enforce a ruling.

This provision does not say much about the role of the judge. Moreover, one can question its internal coherence: if the prime objective is to secure a MAS, why not privilege mediation, a technique supremely adjusted to the specificities of resolving disputes amicably, instead of relegating it to a second order option? Or, why not introduce the possibility for ex aequo et bono litigation, whereby recourse is made to the "fairness" of adjudicators, instead of a legalistic approach, which is ill-suited to compromises?

We do not address these questions here. The law and economics literature has been struggling to operate a distinction between good- and bad faith disputes, which could help decide which provisions need to be re-negotiated for example, and which not. It has not gone far. Few would disagree with the

4 By "property rules", we understand the specific performance of contractually agreed arrangements. "Liability rules" refer to the possibility for a party bound by contractual obligations to "buy its way out of the contract", see Kaplow and Shavell (1996), and Shavell (2003), for a lengthier explanation, and how these rules affect litigation behaviour. 
statement that the GATT (and the WTO subsequent agreements) are incomplete contracts, in the sense that the adjudicator might, on occasion, need to go beyond the text in order to meaningfully interpret the various provisions embedded therein. For reasons first expounded by Baldwin (1970), what is at issue are unavoidably incomplete agreements. Horn, Maggi, and Staiger (2010) have developed a framework that recognizes this context, in which they regard the role of the judge as akin to completing the contract. What matters in this framework is that judges (i.e., the $\mathrm{AB}$ ) are agents, and have no choice but to embark in this exercise, but must do so without altering the will of the principals, the WTO members. The proverbial phrase reflecting this concept is embedded in Article 3.2 of the DSU, which asks adjudicators to respect the balance of rights and obligations struck by the framers.

The problem is that the framers, who negotiated the balance, might on occasion have an incentive to disrespect it. No one has expressed this point better than Tibor de Scitovsky. As noted by John Leddy, de Scitovsky, writing before the advent of the GATT, thought of trade integration in the following terms:

Because of the real or presumed benefits which national governments may anticipate from trade restrictions, and because of the supervening demands of special interest groups, and international free-trade system has a natural tendency to disintegrate and must be enforced by some kind of international convention (Leddy, 1958, referring to Scitovsky 1942).

The GATT (and now the WTO) in other words, is mostly not a coordination game, i.e., a situation where the problem is to agree on a solution that is in the self-interest of all parties to implement. ${ }^{5}$ There are incentives for defection, i.e., non-implementation of what was negotiated. As the WTO is self-enforcing, such defection will be met by retaliation (withdrawal of concessions). Litigation serves the purpose of sustaining the negotiated deal, allowing parties to challenge perceived violations and to ensure that retaliation is both legitimate and proportional. Litigation is therefore an important part of the system. A problem is that it may - and perhaps often does - occur for 'bad' reasons from a cosmopolitan perspective, although theory has not managed to come up with a framework that distinguishes wheat from chaff in this regard. ${ }^{6}$ Good- and bad faith litigation represent the two ends of the spectrum. It is against this background that trading partners met in the Uruguay round aiming to improve the GATT dispute settlement procedures. Wisely, they did not distinguish between the two extremes. Litigation is litigation is litigation, and the same remedies apply irrespective of the good- or bad-faith nature of a dispute.

\subsection{The DSU Negotiators: Doves, Hawks, and the Categories in Between}

The GATT did not contain elaborate dispute settlement procedures. Two provisions (Articles XXII, and XXIII) covered the whole area. Over the years, a series of initiatives were undertaken aiming to address actual issues as they arose. This GATT "pragmatism" instilled confidence in the trading community in the capacity of the GATT to adjudicate disputes. Various GATT decisions added to the original statutory language in Arts. XXII and XXIII. What they all have in common is that they crystallized prevailing practice into regulatory language. ${ }^{7}$

5 The 2013 Agreement on Trade Facilitation is an exception, given that it defines the outcome of a comprehensive discussion to define what constitutes good practices in the area of border management and clearance. It may be that future plurilateral initiatives continue down this route - e.g., a potential agreement on investment facilitation.

6 Speaking of chaff, Grossman and Helpman (1994) have advanced a framework demonstrating the conditions why, in equilibrium, governments might use trade instruments to expose some and shield others from international competition. Similar behaviour could, of course, lead to litigation.

7 There are two excellent accounts of GATT dispute settlement, only partly overlapping. Davey (1987) focuses more on the evolution of the regime over the years, whereas Hudec (1993) provides a very persuasive argument how GATT pragmatism helped transform dispute settlement in the GATT to an (almost) de facto compulsory adjudication regime, paving the way to the so-called Montreal rules (1989) and eventually negative consensus. 
For many, this way of doing things was quite appealing. They were happy to live in a world where only incremental changes would occur, as they believed this was all an increasingly heterogeneous membership could accept. The European Union definitely belonged to this camp. ${ }^{8}$ For some, especially the United States, this was all too little, too late. Disappointed with the impossibility of enforcing dispute settlement outcomes in the realm of farm trade (the European Union would routinely block panel rulings that were adverse to its interests), and the lack of progress in integrating services trade and protection of intellectual property rights into the GATT framework, the US administration took justice into its own hands. "Section 301", "Special 301", "Super 301" became household names, and they all meant roughly the same thing: the US administration would enforce its "rights" unilaterally, that is, without observing GATT Articles XXII and XXIII. ${ }^{9}$ The Uruguay round negotiation on dispute settlement was the multilateral reaction to US unilateralism. The underlying challenge was to define and agree on a dispute settlement system that would persuade the United States to give up its "nuclear option" of unilateral enforcement and anti-systemic behavior. ${ }^{10}$

We can classify the negotiators into four distinct types or groups:

1. The hawk: the United States. From day one, the USA left no one in doubt that it wanted a drastic overhaul, an authentic root and branch reform of dispute adjudication. The foundations of its position were strict deadlines for panels to complete their work, and the removal of the possibility to block establishment of panels and/or adoption of their reports;

2. The doves: led by Japan and Korea, who did not want to undo what had been achieved under the GATT. To them, past practice worked wonders, and consensus was necessary in every step of the way in order to provide the regime with the necessary legitimacy. Brazil, and many developing countries were closer to this line of thinking than any other; ${ }^{11}$

3. The hawkish doves: countries like Australia and Canada, which, unlike the United States, could not enforce the contract unilaterally (at least, not against the big players, against who they had often raised disputes in the past). These countries were prepared to support the US quest for change, even though they did not see eye to eye with the US delegation on all issues, and certainly lacked its gung-ho attitude. They would follow (up to a certain point at least), but would not lead;

4. The dovey hawk: the European Union, which enjoyed enough bargaining power to behave unilaterally, but which had abstained from doing that in the past. In this, as in many other areas, the EU became the "honest broker", the proverbial intermediary who held the pen during the drafting stage, helped iron out differences, and secured the eventual compromise.

It is no exaggeration to suggest that the holy grail of the DSU negotiations was how to combat US unilateralism. As we have already suggested, and numerous accounts have made it clear, ${ }^{12}$ the key question for negotiators was what kind of changes in the GATT would persuade the United States to abandon unilateralism. The road to change was not a straight one. Some trading nations were opposed to change. Indeed, in the beginning, the US delegation was quite isolated. Eventually, it was the countries opposing change - the doves - that were left isolated and ultimately decided to jump on the US bandwagon.

8 Ehlermann (2015).

9 Various contributions in Bhagwati and Patrick (1991) underline this point. Mavroidis (2016), based on the negotiating record, showse how a more effective dispute settlement system was the quid pro quo for the US administration to do away with unilateral measures.

10 It is an open - and important - question whether the current pursuit of aggressive unilateralism by the Trump administration will generate similar dynamics. A major part of the solution was of course the negotiation of new substantive rules in areas of interest to the US (as well as other countries). Arguably a similar process is needed today (see e.g., Hoekman, 2019; McDougal, 2018).

11 Unavoidably, as with any taxonomy, some marginal players could be classified under neighboring categories.

12 Mavroidis (2016) provides a comprehensive review of the literature on this question, as well as the negotiating record. 
Negotiating Group (NG) 13 was the body in which changes in dispute adjudication were negotiated. It was staffed with some of the most experienced trade experts. The Chair was Julio Lacarte-Muro, from Uruguay, ever-present in the GATT since its original negotiation, and later a member of the first AB. He was occasionally replaced by Ambassador Julius Katz, a seasoned US delegate. NG13 included several other experienced and respected figures from national administrations. ${ }^{13}$

\subsubsection{The United States: Gung-Ho for Change}

The original US proposal rested on three pillars:

- It identified stalling as the key issue that needed to be addressed. Disputes would not be resolved expeditiously, and sometimes not at all;

- It further expressed its skepticism regarding the quality of panelists chosen to serve panels. This is a time when the GATT counted few lawyers in its staff, and its Legal Affairs Division was in statu nascendi; ${ }^{14}$

- The US delegation was quite cautious only in its first submission. It did not propose that the GATT should do away with the consensus-rule for voting immediately. The first time, it signaled the issues, and left it for later to go for a root and branch reform. ${ }^{15}$

The US position evolved rapidly. Within two months, in the next document it submitted to NG13, ${ }^{16}$ the US called for binding arbitration, fixed time-limits for the duration of consultations, automatic establishment of panels (that is, negative consensus), and, as per the "Leutwiler report", ${ }^{17}$ the establishment of roster of non-governmental panelists. This last proposal was motivated by the premise that governmental panelists might be prone to listen to their own government when deciding on specific matters raised in a dispute. Along with the proposal for automatic establishment of the panel these were the two more far-reaching proposals. Whereas the United States could invoke the Leutwiler report with respect to the use of exclusively non-governmental panelists, the proposal for automatic establishment of panels was its own.

The US delegation was prepared to negotiate three distinct options, as far as adoption of panel reports was concerned:

- Consensus minus two, that is, panel reports would be adopted by the GATT membership, but the parties to the dispute would have no vote in this respect;

- Panels issuing binding reports, that is, negative consensus would extend to the adoption of reports; or

- Alternatively, in the absence of consensus, the adoption of reports would be considered in the GATT Council, or before the relevant committee (on antidumping, safeguards, etc.).

Expedited procedures were a priority item for the United States. In various documents, the US delegation repeated that the phrase "not unduly obstruct the process" used on occasion by both Japan and the European Union to delineate unacceptable policies, was unclear and inadequate. Clear deadlines, automaticity in the establishment of panels, and moving towards negative consensus were key features

13 See for example the list of delegates in GATT Doc. MTN.GNG/NG13/INF/1 of September 21, 1987.

14 Lindén (2016), Petersmann (2016), and Roessler (2016) discuss the advent of the first GATT Legal Office in separate and only partially overlapping contributions.

15 Initial US negotiating position in GATT Doc. MTN.GNG/NG13/W/3 of April 22, 1987.

16 GATT Doc. MTN.GNG/NG13/W/6 of June 25, 1987.

17 The then Director-General of the GATT, Arthur Dunkel, had invited Fritz Leutwiler to head a group of seven luminaries, and prepare a report on the way forwards for the GATT (https://docs.wto.org/gattdocs/q/GG/GATTFOCUS/33.pdf). The final report was published as "Trade Policies for a Better Future: the 'Leutwiler Report', the GATT, and the Uruguay Round”, Martinus Nijhoff Publishers, Dordrecht, the Netherlands, 1987. 
that were non-negotiable for the US. ${ }^{18}$ Conversely, the US delegation was willing to compromise elsewhere. Eventually, for example, when it realized that it was isolated on this score, it stopped pressing for exclusive recourse to non-governmental panelists. ${ }^{19}$ The establishment of an appeals mechanism was not a feature of US proposals: it did not propose an $\mathrm{AB}$ as a compensatory mechanism for its proposal in favor of negative consensus.

\subsubsection{Japan, Korea and Other Doves: No Change Required}

Japan and Korea led the chorus of countries that suggested there was little need to tinker with the GATT regime. More than anything else, they were unwilling to undo the need for consensus for panel reports to be adopted. Japan was prepared to see some changes in the regime, but they were all in favor of trading nations keeping control of the process. For example, Japan wanted each party to a dispute to have the right to nominate one arbitrator, whereas the Director-General could be entrusted with the nomination of the umpire. Preferably, all panelists should be governmental. ${ }^{20}$ Japan understood the process to be predominantly conciliatory, and not adjudicatory, and the nominated panelists should commit to working towards this objective. ${ }^{21}$ Korea largely agreed with Japan, but assuming an amendment across all participants could be agreed, it would not oppose binding arbitration. ${ }^{22}$ Korea nevertheless, retained that, absent an agreed amendment to this effect, arbitration should be non-binding. Mediation should become the dominant mode for resolving disputes. The right to a panel should not be acknowledged, but panel proceedings should not exceed nine months. ${ }^{23}$

Korea and Japan received some support from developed countries like Switzerland ${ }^{24}$ and the European Union, ${ }^{25}$ as well as from a few developing countries, like Brazil. The latter emphasized the role of developing countries and insisted on conciliation as the key element for dispute adjudication in the GATT. ${ }^{26}$ In a similar vein, Mexico emphasized that consensus should be a requirement for adoption of panel reports. ${ }^{27}$ These voices became the minority opinion quite early on in the negotiating process. The doves, like Japan and Korea, did not include any mention of an appeals board (an AB) in their proposals.

\subsubsection{Australia, Canada, and the Hawkish Doves: Yes to Change (in Principle)}

Various countries in this group submitted comparable proposals, largely echoing the quintessential elements of the US submissions. Australia favored strict time limits for each phase of the dispute adjudication; explicit acknowledgment of the right to a panel; and endorsed the "consensus minus two" formula. ${ }^{28}$ The Nordics (Finland, Norway, and Sweden) were willing to support recourse to binding arbitration and right to a panel. ${ }^{29}$

\footnotetext{
18 GATT Doc. MTN.GNG/NG13/4 of November 18, 1987.

19 GATT Doc. MTN.GNG/NG13/8, of July 5, 1988.

20 GATT Doc. MTN.GNG/NG13/W/9 of September 18, 1987.

21 GATT Doc. MTN.GNG/NG13/3 of October 12, 1987.

22 GATT Doc. MTN.GNG/NG13/3 of October 12, 1987.

23 GATT Doc. MTN.GNG/NG13/W/19 of November 20, 1987.

24 GATT Doc. MTN.GNG/NG13/3 of October 10, 1987.

25 GATT Doc. MTN.GNG/NG13/5 of December 7, 1987.

26 GATT Doc. MTN.GNG/NG13/W/24 of March 7, 1988.

27 GATT Doc. MTN.GNG/NG13/7, of May 11, 1988.

28 GATT Doc. MTN.GNG/NG13/W/11 of September 24, 1987.

29 GATT Doc. MTN.GNG/NG13/3 of October 10, 1987.
} 
Canada placed the accent on MFN in the context of adjudication. To this effect, it declared its willingness to support introduction of binding arbitration, under the condition that third parties' rights were protected. Canada wanted to avoid a situation whereby litigating parties would end up reaching solutions that would not observe MFN and was eager to enhance transparency through which third parties could avail their rights. It also endorsed the right to a panel and supported the idea of putting together a roster of qualified panelists, although in its view this need not be limited to non-governmental persons. ${ }^{30}$ In a subsequent joint proposal that Canada tabled with Argentina, Hong Kong, China, Hungary, Mexico, and Uruguay, it reaffirmed its support for the right to panel, and advocated an enhanced role for the GATT Director-General, as well as the Chairman of Dispute Settlement Council in adjudication. The proposal did not define what exactly the enhanced role would comprise, but it was clear that those who had signed the proposal thought of it as yet another move towards third-party adjudication and less interference in the process by the litigating parties. ${ }^{31}$ An appeals board was not proposed by any of these countries during the initial stages of the negotiation.

\subsubsection{The European Union: Reluctant Supporter of Change}

The European Union changed its attitude over time, as it did in other areas of the Uruguay round as well. As mentioned, initially it sided with the doves, but subsequently its position evolved to move closer to that of the US, even though not wholeheartedly so. ${ }^{32}$ The EU declared its willingness to support recourse to binding arbitration, but suggested this be limited to a few cases, which, it submitted, negotiators would need to define. It was prepared to support the acknowledgment of the right to panel, but, in its view, the adoption of panel reports would require consensus. Finally, in the EU view, recourse to governmental panelists remained preferable. ${ }^{33}$

The EU delegation did not change its attitude overnight. Eventually, it did not object to the changes required by the US delegates, especially since the quid pro quo would entail that Section 301 would be limited to an instrument of diplomatic protection. In the interim it submitted proposals that aimed to sugar-coat the position of doves, or at best, implied meeting the United States half way. The most imaginative proposal was to dissociate the question of GATT-conformity of challenged measures from the question of remedies in case of finding that the challenged measures were GATT-inconsistent: whereas the former could be adopted by negative consensus, the latter should be approved if there was a consensus to this effect. If consensus proved impossible, the GATT Council was simply to take note of reports. ${ }^{34}$

The EU suggestion was opposed by other parties. The most persuasive argument against it was that by dissociating findings on conformity from remedies, it would lead to authentic interpretations of the GATT. In fact, those disagreeing with the EU feared that a hierarchy between the various types of findings would be introduced. Findings of conformity would suffer from less legitimacy in the eyes of the membership. If the ensuing remedy would also be agreed by the losing member, then these findings would, ipso facto, increase their legitimacy. Consensus with respect to remedies would thus confer findings on conformity with an accretive legitimacy-effect. It would transform them to something akin to authentic interpretations, a privilege bestowed to the WTO membership only. Such an outcome would be worse than the binding precedents that the European Union and others wished to avoid. ${ }^{35}$ Since the EU delegation was not a strong supporter of negative consensus, it should come as no surprise that it

\footnotetext{
30 GATT Doc. MTN.GNG/NG13/W/13 of September 24, 1987.

31 GATT Doc. MTN.GNG/NG13/W/16 of November 11, 1987.

32 Ehlermann (2015).

33 GATT Doc. MTN.GNG/NG13/W/12 of September 24, 1987.

34 GATT Doc. MTN.GNG/NG13/W/22, of March 2, 1988.

35 GATT Doc. MTN.GNG/NG13/6, of March 31, 1988.
} 
did not favor tinkering with the GATT rules. As with the other groups, there was no place for an appeals board in the EU's proposed adjudication model.

\subsection{The GATT Secretariat: Honest Broker}

The GATT Secretariat played an important role throughout the negotiating process. It did not exercise initiative, but whenever requested, it provided excellent papers, which clarified the status quo of the GATT dispute adjudication system, and, as a result, provided accurate and pertinent information to negotiators to help them assess the pros and the cons of the regime. This information helped nudge the negotiators in one or another direction. Among the various documents produced, we single out the following:

- A remarkable document, ${ }^{36}$ in which the Secretariat explained the status of all disputes formally raised before the GATT since 1947, providing a 'single window' for negotiators permitting them, inter alia, to check the identity of parties, the subject-matter of disputes, the rate of adoption of panel reports, and the final resolution of disputes;

- Several papers explaining the changing nature of disputes, focusing on the more recent and ongoing disputes. ${ }^{37}$ These pointed to the falling rate of adoption of panel reports, and provided a basis for deliberation why this was the case, e.g., whether this reflected the subject-matter of disputes, the identity of the players, increasing homogeneity of the players, a combination of the reasons above etc.;

- Other papers by the Secretariat dealing with specific topics, including:

- Non-violation complaints (NVCs), including a focus on the compensation that was agreed as an interim solution pending resolution of disputes; $; 3$

- The types of complaints that had been brought forward and the rationale for maintaining the option of diplomatic resolution of disputes in the statutes - the argument that this reduced the potential for a situation where one party is victor, and one a loser, helping to preserve the prestige of all involved in a dispute, $;^{39}$

- An evaluation of the usefulness of the 1966 procedures intended to support the participation of developing countries in dispute adjudication. The Secretariat paper notes that these procedures were invoked only 4 times, even though there were 107 complaints in total up to 1988,20 of which were raised by developing countries. ${ }^{40}$ This paper cast doubt on the meaningfulness of replicating similar procedures in the future and continued working on special and differential treatment in more general terms. ${ }^{41}$ It revealed that little use had been made of provisions aimed to help developing countries, and that usefulness of such processes might need rethinking. Either the procedures would have to be modified, or the whole idea of a two-tier process would have to be rethought ab initio.

- Overviews and summaries of proposals submitted during the negotiation of the Uruguay round. These documents made clear, for example, that there was increasing adherence to

\footnotetext{
36 GATT Doc. MTN.GNG/NG13/W/4, of June 10, 1987.

37 GATT Doc. MTN.GNG/NG13/W/28, of July 5, 1988.

38 GATT Docs. MTN.GNG/NG13/W/32, of July 14, 1989; MTN.GNG/NG13/15 of July 26, 1989; MTN.GNG/NG13/16 of November 13, 1989.

39 GATT Doc. MTN.GNG/NG13/W/20, of February 22, 1988.

40 GATT Doc. MTN.GNG/NG13/W/27, of June 30, 1988.

41 GATT Docs. MTN.GNG/NG13/9, of September 21, 1988; MTN.GNG/NG13/W/14, of June 2, 1989.
} 
the view that the selection of panelists be entrusted to the Director-General in cases where the parties could not agree. ${ }^{42}$

Thus, despite not having a right of initiative, the Secretariat managed through its papers to steer the discussion towards the major issues that had plagued dispute adjudication, while highlighting the many positive aspects of prior experience.

\subsection{The Negotiation of the $A B$}

At the end of 1988, the GATT Secretariat circulated a draft DSU, a document reflecting the status of negotiations up to that point. There was no mention of an appeals board and no party objected to the draft. ${ }^{43}$ As we discuss below, matters did not change until the end of 1989. The first three years of the Uruguay Round negotiation record therefore reflects no discussion at all of an appeals board. This suggests an appeal mechanism was not a priority issue for any of the negotiating partners.

\subsubsection{Canada Shoots First}

An originally un-identified country first tabled a proposal for a body entrusted with the task to perform appellate review in December 1989, ${ }^{44}$ only two years before end of substantive negotiations (by the time of circulation of the Dunkel Draft in December 1991 the DSU negotiations had been concluded). The proposal to establish an appeals board came from Canada. ${ }^{45}$ The thinking was that an appeals board would function as a sort of fast-track procedure, with reviews completed within 30 days. Fast track, in Canada's eyes, would discourage routine recourse to appeals after a panel report was issued. Canada left the composition of an appeals board open, stating no preference in favor of either a standing tribunal or a roster with potential members.

The various negotiating documents reveal that no one opposed the Canadian proposal. Many submitted papers sought to streamline and improve the original proposal for an appeals board, but no one outright rejected the idea. The US delegation felt that it was a right price to pay (a bit of delay in proceedings), in order to secure the advent of its priority items (right to a panel; negative consensus; strict time-limits). Japan, and Korea thought of an appeals board as an additional layer of legitimacy, extra time to reconcile before impartial judges. Australia, the European Union, and developing countries tagged along as well. An appeals board could, in principle at least, be seen either as additional push towards rules-oriented regime and/or another bite at the conciliation pie.

Steger (2015), citing various sources including negotiators, has argued that the advent of the AB was the quid pro quo for parties losing the right to block adoption of reports. This is definitely a plausible explanation for all but the United States, which had argued for negative consensus irrespective of an appeals board, as we have noted above.

\subsubsection{Negotiating Article 17 of the DSU}

There are few negotiating documents on what became Art. 17. Most were prepared by the GATT Secretariat. The most salient features of the negotiation were:

- The expressed will to avoid procrastinating resolution of disputes because of the advent of an appeals board. To this effect, both recourse to this body should not be encouraged, as well

42 GATT Doc. MTN.GNG/NG13/W/2, of July 15, 1987.

43 GATT Docs. MTN.GNG/NG13/W/29, of August 8, 1988, and MTN.GNG/NG13/10, of October 4, 1988.

44 GATT Doc. MTN.GNG/NG13/17, of December 15, 1989.

45 Steger (2015). Debra Steger was the Canadian negotiator in charge of the DSU negotiation, as well as the first Director of the Legal Service of the AB. 
as statutory deadlines should be fixed; ${ }^{46}$ The European Union emerged as the broker in this respect, playing an active role in the discussion of deadlines, which, when combined with the panel process, replicated to some extent those in US Section $301 ;^{47}$

- The United States preferred a fixed pool of experts. ${ }^{48}$ Originally, the idea was to put together a small body of 3 judges, with 4 more acting as alternates. ${ }^{49}$ Canada's original proposal to leave it open, potentially, to a larger roster of members (and the ensuing ad hoc composition) was soon abandoned;

- The United States believed that the GATT Council was not an appropriate forum to discuss legal interpretations, noting it only saw a role for such discussion in extraordinary circumstances. It was more comfortable with an appeals board comprising a pool of judges entrusted with this competence. ${ }^{50}$ In a subsequent Secretariat document, we find the language "uphold modify reverse", which captures the current scope of the AB review as we now know it. When doing that, the appeals board should limit itself to issues of law. ${ }^{51}$

\subsubsection{The Dunkel Draft and the shift from NG13 to the Legal Drafting Group}

The Dunkel draft (December 1991) signals for all practical purposes the end of negotiations on the substantive elements of the $\mathrm{AB}$. It made clear that it would be limited to a review of legal issues, and that it could uphold, reverse or modify panels' rulings. The 60-day deadline within which, in principle, the $\mathrm{AB}$ should reach its decision, was also decided at this stage as well, as was the need to aid its workings through the provision of technical support. What remained an open issue was the membership. While it was clear that only three would decide any given case, whether the total membership would span three or five members and four alternates remained to be determined. ${ }^{52}$

In the remaining two years of the Uruguay round (1991-1993) work moved from NG13 to a new group, the Legal Drafting Group. This group was convened under the leadership of Deputy DirectorGeneral, M.G. Mathur, an old GATT hand with vast experience on institutional matters. The main objective of this group was to review the legal conformity and internal consistency of the Dunkel Draft. It started work on January 23, $1992 .{ }^{53}$ Top lawyers and trade experts participated in the group. ${ }^{54}$ From day one, M.G. Mathur made it clear to all that deliberations by the group could not lead to changes in the balance of rights and obligations established through the negotiations as these had been concluded. ${ }^{55}$ The mandate was to improve the expression in the various provisions that had been agreed, without altering their scope.

At that time, the WTO was still referred to as the MTO (Multilateral Trade Organization). Besides linguistic scrubbing, the idea was to ensure that dispute settlement would be coherent throughout all agreements coming under the aegis of the MTO, and not confined to GATT-use only. ${ }^{56}$ The Secretariat emerged as key player in this process, as it was entrusted with the streamlining the final text of the DSU,

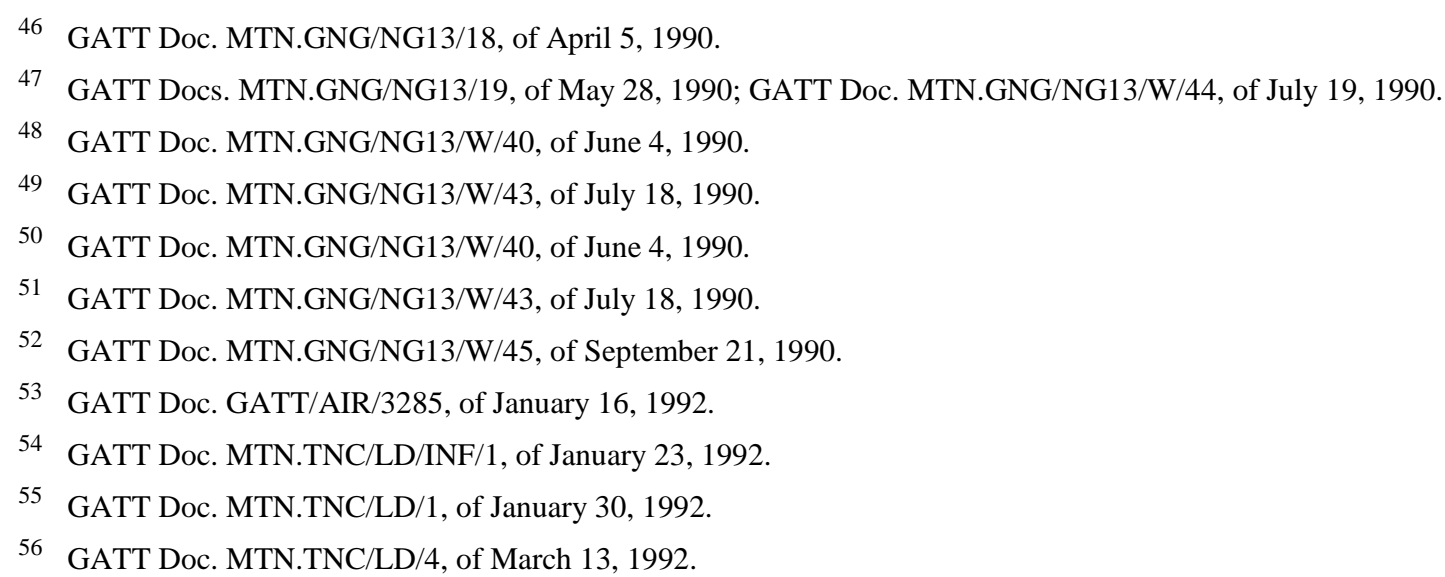


based, of course, on instructions that it would receive from delegates to this group. ${ }^{57}$ The group held a few formal, but also various informal meetings in order to complete its work. ${ }^{58}$ Before issuing the final text, the current DSU, M.G Mathur circulated a text comparing the work of the group with the text as embedded in the Dunkel Draft. ${ }^{59}$ Following one last reading, it was sealed and approved. The AB had found its place in the world trading system.

\section{The US Complaints against the $A B$ in light of the final UR text}

The purpose of what follows is not to provide an elaborate legal assessment of the merits of US complaints regarding the operation of the $\mathrm{AB}$. Instead, the aim is to juxtapose the US complaints against the agreed text and function of the AB. We discuss the US complaints as formulated in various informal papers and in interventions before the DSB (Dispute Settlement Body). We do not consider arguments that the US (or other delegations) have advanced before the ongoing DSU Review.

The United States has advanced three complaints:

- The $\mathrm{AB}$ has undone the balance of rights and obligations by outlawing zeroing in antidumping investigations. It should have been led to the opposite conclusion, since, as per Article 17.6 of the Agreement on Antidumping, zeroing is a "permissible" interpretation of dumping margin. Nevertheless, by practically reading out this provision as well, the AB has outlawed zeroing, which the US domestic authorities practice;

- The AB has mischaracterized factual as legal issues, and, as a result, it has expanded its jurisdictional scope against the letter and the spirit of the DSU;

- Finally, the AB has not respected the statutory deadlines for issuing its reports.

On occasion, the US delegation has also complained about aspects of AB activities. One of these is the use of Rule 15 of the AB Working Procedures. According to this provision, an outgoing member of the $\mathrm{AB}$ can still serve in a division, if he/she was appointed before the expiry of his/her term. This argument seems to have subsided, and we do not discuss it in what follows. Another dimension of US skepticism concerns the precedential value of $\mathrm{AB}$ reports. Since mistakes can occur, why repeat them, so the thinking goes. Consistency is not a value in and of itself, since one can be consistently wrong. Two remarks are in order one this question. First, the US delegation has not made this a key point of contention. Indeed, the US, when a complainant, consistently refers to prior case law in its pleadings. Second, and more substantively, if the role of the $A B$ is limited to interpretations of law, some precedential value of its findings is unavoidable. Indeed, understanding the law irrespective of the underlying facts is almost synonymous to the term "precedent". So, either the role of the AB has to be re-thought (raising the fundamental question what value a second panel can bring), or the WTO membership has to accept "precedential" value.

To avoid misunderstanding, we note that this does not imply that precedents must be followed without considering their usefulness. Indeed, the role of Supreme Courts in common law systems is, among other things, to rethink the usefulness of precedents and modify them, if warranted. In the absence of a Supreme Court, the $\mathrm{AB}$ should be in position to change its mind, provided it justifies the reasons for doing so. A similar construction makes sense, and would take care of the heart of the concerns expressed by the US. To paraphrase Lord Keynes, when confronted with new information, a reasonable person changes their mind.

\footnotetext{
57 GATT Doc. MTN.TNC/LD/6, of May 22, 1992.

58 See, for example, GATT/AIR/3380, of November 30, 1992, and GATT/AIR/5546, of January 28, 1994.

59 GATT Doc. MTN/FA/Corr. 5 of March 11, 1994.
} 


\subsection{Zeroing in Light of the Antidumping Standard of Review}

Zeroing refers to the practice of not considering negative dumping margins when calculating the dumping margin in an antidumping investigation. Case law on this is incoherent: the $\mathrm{AB}$ has consistently outlawed zeroing, whereas panels, in defiance of the $\mathrm{AB}$ ruling expressed in Mexico-Stainless Steel that they should observe relevant $\mathrm{AB}$ findings - another feature of $\mathrm{AB}$ behavior to which the US objects have on various occasions ruled otherwise. ${ }^{60}$

To understand the merits of the US claim, the following elements are salient:

- The absence of explicit regulation of zeroing in the Agreement on Antidumping;

- The obligation of investigating authorities to perform a fair assessment of dumping margins (Article 2.4 of the Agreement on Antidumping);

- The obligation of panels to perform an objective assessment of matters before them (DSU Article 11);

- The additional obligation of panels to accept permissible interpretations by investigating authorities, as per Article 17.6 of the Agreement on Antidumping.

\subsection{Treatment of Issues of Facts and Law}

The US claim is that the AB has on occasion treated issues of facts as issues of law. It cites the treatment of municipal law as a paradigmatic illustration to this effect. To review the legitimacy of the US claim, the following elements seem pertinent to us:

- The obligation of panels to perform an objective assessment of the matter before them (Article 11 of the DSU);

- Article 1.1 of the DSU mentions that disputes can arise under the covered agreements (domestic law does not fall under the covered agreements);

- Case law has consistently suggested that domestic law can be reviewed by panels as an issue of fact. The $\mathrm{AB}$ has never taken distance from this jurisprudence.

\subsection{Respecting Time-Limits}

The US claim here concerns disrespect of statutory deadlines solely by the AB, even though empirical evidence suggests that it is panels that are the major culprits on this front. Article 17.5 of the DSU, which states that the $\mathrm{AB}$ should complete its work within 60 days from the day when a notice of appeal has been filed. In exceptional cases, this deadline could be extended to ninety days (with the agreement of the parties). Johannesson and Mavroidis (2017) document that the AB has by and large adhered to the statutory deadlines. This changed in 2018-19 but that reflects in large part the fact that the AB began to operate in diminished capacity as a result of the US decision not to renew members whose term was expiring. In a sense, it is inflicted damage.

\section{Concluding Remarks}

US grievances started when the AB confirmed that zeroing was illegal. They reached their zenith when the $\mathrm{AB}$ closed the door to zeroing even in instances where recourse was made to the exceptional method, that is, the weighted average to transaction comparison methodology (Mavroidis and Prusa, 2018). The US authorities obtained some solace when panels decided to deviate from the AB ruling in this respect, but the US never got what it wanted: the $\mathrm{AB}$ did not flinch. This probably explains why US criticism is directed towards the $\mathrm{AB}$, and not towards panels, even though panels have on occasion committed some

60 Mavroidis and Prusa (2018) discuss the case law on this score. 
of the sins the US accuses the AB of. Indeed, one might wonder whether the US would have mounted its criticism with the same tenacity, whether it would have stopped appointments of its members, had the $\mathrm{AB}$ agreed with those panels that found that zeroing was WTO-consistent.

We do not side with those who take the view that all is good as far as the AB is concerned. There is room for a lot of improvement both in terms of the quality of the output, as well as from an institutional perspective. But we do not believe that the AB's stance on zeroing should be the reason for its downfall. WTO members should not throw the baby out with the bathwater, even if the AB has disappointed on a few occasions.

The negotiating record and the final WTO text help to clarify what the AB "as conceived and agreed in 1995 " needs to do to address the specific matters raised by the United States. The DSU does not define issues of fact and issues of law, but the distinction between the two should be crystal clear, especially to experienced judges. The same is true regarding the power of $\mathrm{AB}$ rulings and the extent to which they should be considered as precedent setting. The situation is also clear with respect to time limits. We have explained our views on these elements in the preceding section.

The situation is more ambiguous on zeroing, as the text permits greater discretion. Undeniably, panels and the $\mathrm{AB}$ have only paid lip service to the wording of Article 17.6 of the Antidumping Agreement. It seems that they have reduced the term "permissible interpretation by investigating authorities" (Art. 17.6 Antidumping Agreement) to redundancy. The question is whether zeroing is a permissible interpretation of dumping margin. In Mavroidis and Prusa (2018) we responded in the negative. This does not imply US criticism is futile. The AB could have done many things better. In our view, any constructive critique is to be welcomed. What we find difficult to support is the manner in which the US voiced its critique. Using the WTO working practice of consensus to block all new AB appointments is no doubt an effective mechanism to force WTO members to consider the US claims, but destroying the village to save it is hopefully not the mindset that will prevail. The US should work with the WTO membership to resolve the situation.

Given the long-standing preference of all WTO members not to resort to voting in the WTO (notwithstanding this being provided for by the agreement establishing the WTO), the pragmatic path forward is to take seriously the US position that it does not desire to go "back to the GATT," that is, is not questioning the two-stage dispute settlement process agreed in the Uruguay Round. If what is required is to bring WTO dispute resolution "back to 199." as reflected in both the DSU text and the negotiating record, then there is no reason why the WTO membership should oppose this. Doing so would constitute a monumental failure of collective leadership. A collective (re-)commitment to this effect, including agreement to put in place procedures to hold the $\mathrm{AB}$ accountable for operating within this mandate, would not imply re-opening the DSU.

Failure by the US to join such a commitment by the WTO membership would be an act of destruction. The WTO DSU is the only extant compulsory third-party adjudication regime in international relations. Undoing it might lead to a domino effect, a perilous prospect by any reasonable benchmark. Insofar as the US stance results in an understanding that some things that were taken for granted need to be revisited it may provide a (welcome) wake-up call for the world trading community to work together to improve the operation of the WTO.

In 2002, a former AB member, Claus-Dieter Ehlermann, referring to the WTO dispute adjudication system, prophetically stated: "It seems to me wise not to take its existence for granted, and to be guaranteed forever, but to contribute to its consolidation and further development ..." (Ehlermann, 2002). His ominous prophecy seemed a remote possibility when he authored this paper, and yet a few years later it has all but materialized. Many former $A B$ members are eloquent in their praise of the contribution of $A B$ to the world trading regime. Lacarte-Muro (2015) and Ganesan (2015) think the AB has made a clear contribution to the rule of law. But $A B$ members disagree on various aspects of its function. This is something we all should keep in mind. The covered agreements, for reasons that have been explained in the economics literature, are 'incomplete' and sometimes 'highly incomplete' 
contracts (e.g., Horn et al., 2010). Those called to interpret them must be entrusted with some margin of discretion. The risk of doing so is not a mere theoretical possibility. Indeed, going through the writings of the $\mathrm{AB}$ members, we realize that they do not necessarily speak with one voice. It is not that they enjoy some discretion almost by construction. It is also that they do not necessarily agree on how to use this discretion.

The Vienna Convention on the Law of Treaties, the agreed means to interpret the covered agreements, is not a mathematical formula. It cannot guarantee that interpreters will not overstep their mandate, even though it does circumscribe in aggregate terms their function. The major weakness is that it does not include a weighing of the various elements it contains: how much more should a judge defer to context compared to plain text, for example? Zhang (2015) understands it as a move away from diplomatic resolution of disputes to a quasi-judicial approach. And yet, Matsushita (2015) insists in underlining the primary responsibility of the membership (p. 550):

Negotiators at the Uruguay Round negotiations did not wish to create an independent court of international trade with decision-making power distinct and separate from that of the WTO members ... Negotiating parties wanted the WTO to be a member-run organization where the membership has the ultimate power to decide everything ...

$\mathrm{AB}$ members understanding whether they can use extra-WTO law to resolve disputes is also not harmonious. Bacchus (2015) sees no problem at all embarking on extra-WTO law to resolve disputes brought before the $\mathrm{AB}$ (p. 515):

There is nothing in the WTO treaty to suggest that the applicable law available to panels and the Appellate Body in fulfilling their responsibilities to the members of the WTO is limited to the covered agreements. When necessary to do their job, WTO jurists can range far and wide in other international law. But it seems clear that the substantive jurisdiction of WTO jurists is limited to claims under the covered agreements.

But this is precisely what the United States has taken issue with. This expansive view does not bode well as far as some stakeholders are concerned. Luyten (2015), never an AB member but a very experienced high official of both the GATT as well as the European Union, spoke for those disagreeing when stating that (p. 84):

It seems to me that a tendency toward legalization of the trading system has led lawyers to sometimes partly take over from negotiators, filling gaps, reinterpreting, and, at the limit, even restructuring agreements under the guise of interpretation.

Criticism is unavoidable. It simply cannot be, as Olavo Baptista (2015), another former AB member wrote, that the source of the pushback against the $\mathrm{AB}$ simply reflects sour grapes by those who have lost their argument before the AB. The question is what to do to respond to criticism. Whether the extent of criticism can be reduced is also important, but preventive action along the lines of the different "plan B' proposals put forward by the EU and other WTO members are in our view insufficient. This is not only because they imply an unwillingness to address the criticism, but because pursuit of plan B is likely to impede the prospects of broader WTO reform and the negotiation of new agreements. Much needs to done to update the WTO rulebook and WTO working practices (Bertelsmann Stiftung, 2018; Hoekman, 2019). Continued deadlock on the $A B$ will impede the pursuit of this broader agenda.

Our discussion in this paper suggests "going back to 1995"should not be particularly difficult or fraught, assuming good faith and good will. Presently this is in very short supply, but the feasibility of reaching an understanding should be enhanced given that addressing the purported US concerns does not require re-opening or revising the DSU. That of course is not to say that WTO reform discussions should not also span the dispute settlement system. ${ }^{61}$

\footnotetext{
${ }^{61}$ See McDougal (2018) for concrete suggestions and WTO (2018) for a synthesis of WTO deliberations to date on reform of the DSU.
} 


\section{References}

Bacchus, James. 2015. Not in Clinical Isolation, in Gabrielle Marceau (ed.), A History of Law and Lawyers in the GATT/WTO, Cambridge: Cambridge University Press, pp. 507-516.

Baldwin, Robert E. 1970. Non-Tariff Distortions of International Trade, Brookings Institution: Washington, D.C.

Bertelsmann Stiftung. 2018. Revitalizing Multilateral Governance at the World Trade Organization. Report of the High-Level Board of Experts on the Future of Global Trade Governance.

Bhagwati, Jagdish, and Hugh Patrick (Eds.). 1991. Aggressive Unilateralism, America's 301 Trade Policy and the World Trading System, University of Michigan Press: Ann Arbor, Michigan.

Davey, William J. 1987. Dispute Settlement in GATT, Fordham International Law Journal, 11: 51-99.

Ehlermann, Claus-Dieter. 2015. Revisiting the Appellate Body: the First Six Years, in Gabrielle Marceau (ed.), A History of Law and Lawyers in the GATT/WTO, Cambridge University Press: Cambridge, United Kingdom, pp. 482-506.

Ganesan, A.V. 2015. The Appellate Body in Its Formative Years: a Personal Perspective, in Gabrielle Marceau (ed.), A History of Law and Lawyers in the GATT/WTO, Cambridge: Cambridge University Press, pp. 517-546.

Grossman, Gene M., and Elhanan Helpman. 1994. Protection for Sale, American Economic Review, 84: 833-850.

Hoekman, Bernard. 2019. Urgent and Important: Improving WTO Performance by Revisiting Working Practices, Journal of World Trade, 53(3): 373-94.

Horn, Henrik, Giovanni Maggi, and Robert W. Staiger. 2010. Trade Agreements as Endogenously Incomplete Contracts, American Economic Review, 100: 394-419

Hudec, Robert E. 1993. Enforcing International Trade Law, Buttersworth: London, United Kingdom.

Johannesson, Louise, and Petros C. Mavroidis. 2017. The WTO Dispute Settlement System 1995-2016: a Data Set and its Descriptive Statistics, Journal of World Trade, 51: 357-408.

Kaplow, Louis, and Steven Shavell. 1996. Property Rules vs Liability Rules; an Economic Analysis, Harvard Law Review, 109: 713-790.

Lacarte-Muro, Julio. 2015. Launching the Appellate Body, in Gabrielle Marceau (ed.), A History of Law and Lawyers in the GATT/WTO, Cambridge: Cambridge University Press, pp. 476-481.

Leddy, John. 1958. "GATT-A Cohesive Influence in the Free World," American Journal of Agricultural Economics, 40(2): 228-37.

Lindén, Åke. 2016. The First Years of the GATT Legal Service, in Gabrielle Marceau (ed.), A History of Law and Lawyers in the GATT/WTO, Cambridge: Cambridge University Press, pp. 135-140.

Luyten, Paul. 2015. We Were Young Together: at the GATT, 1956-58, in Gabrielle Marceau (ed.), A History of Law and Lawyers in the GATT/WTO, Cambridge: Cambridge University Press, pp. 79-84.

Matsushita, Mitsuo. 2015. Reflections on the Functioning of the Appellate Body, in Gabrielle Marceau (ed.), A History of Law and Lawyers in the GATT/WTO, Cambridge: Cambridge University Press, pp. 547-558.

Mavroidis, Petros C. 2016. Mind Over Matter, in Kyle Bagwell and Robert W. Staiger (eds.), Handbook on Commercial Policy, Handbooks in Economics, Elsevier: Amsterdam and New York City, pp. 333-378. 
Mavroidis, Petros C., and Thomas J. Prusa. 2018. Die Another Day: Zeroing in on Targeted Dumping Did the AB Hit the Mark in US-Washing Machines? World Trade Review, 17: 239-264.

McDougal, Robert. 2018. Crisis in the WTO: Restoring the WTO Dispute Settlement Function, Journal of World Trade 52(6): 867-96.

Olavo Baptista, Luiz. 2015. A Country Boy Goes to Geneva, in Gabrielle Marceau (ed.), A History of Law and Lawyers in the GATT/WTO, Cambridge: Cambridge University Press, pp. 559-569.

Petersmann, Ernst-Ulrich. 2016. The Establishment of the GATT Office of Legal Affairs and the Limits of 'Public Reason' in the GATT/WTO Dispute Settlement System, in Gabrielle Marceau (ed.), A History of Law and Lawyers in the GATT/WTO, Cambridge: Cambridge University Press, pp. 182207.

Roessler, Frieder. 2016. The Role of Law in International Trade Relations and the Establishment of the Legal Affairs Division of the GATT, in Gabrielle Marceau (ed.), A History of Law and Lawyers in the GATT/WTO, Cambridge: Cambridge University Press, pp. 161-174.

Scitovsky, Tibor. 1942. A Reconsideration of the Theory of Tariffs, Review of Economic Studies, 9: 89110.

Shavell, Steven. 2003. Foundations of Economic Analysis of Law, Harvard University Press: Cambridge, Massachusetts.

Steger, Debra P. 2015. The Founding of the Appellate Body, in Gabrielle Marceau (ed.), A History of Law and Lawyers in the GATT/WTO, Cambridge: Cambridge University Press, pp. 447-465.

Van den Bossche, Peter. 2006. From Afterthought to Centerpiece, the WTO Appellate Body and its Rise to Prominence in the World Trading System, in Giorgio Sacerdoti, Alan Yanovich, and Jan Bohannes (eds.), The WTO at Ten: the Contribution of the Dispute Settlement System, Cambridge: Cambridge University Press, pp. 289-312.

WTO. 2019. Special Session of the Dispute Settlement Body: Report by the Chairman, Ambassador Coly Seck, TN/DS/31, 17 June.

Zhang, Yuejiao. 2015. Contribution of the WTO Appellate Body to treaty Interpretation, in Gabrielle Marceau (ed.), A History of Law and Lawyers in the GATT/WTO, Cambridge: Cambridge University Press, pp. 570-598. 


\section{Author contacts:}

\section{Bernard M. Hoekman}

Robert Schuman Centre for Advanced Studies, European University Institute Villa Schifanoia, Via Boccaccio 121

I-50133 Florence

and CEPR

Email: Bernard.Hoekman@eui.eu

\section{Petros C. Mavroidis}

Columbia Law School

Edwin B. Parker Professor of Law at Columbia Law School

Jerome Greene Hall, Room 734

435 West 116th Street

New York, NY 10027

Email: pmavro@law.columbia.edu

and

Robert Schuman Centre for Advanced Studies, European University Institute Villa Schifanoia, Via Boccaccio 121

I-50133 Florence

Email: Petros.Mavroidis@eui.eu 